\title{
In search of copassion : Creating a novel concept to promote re-enchantment at work
}

\section{Pessi, Anne Birgitta}

2022-01

Pessi , A B , Seppanen , A M , Spannari , J , Gronlund , H, Martela , F \& Paakkanen , M 2022 , ' In search of copassion : Creating a novel concept to promote re-enchantment at work ' , BRQ-Business research quarterly , vol. 25 , no. 1 , 23409444211058179 , pp. 82-97 . https://doi.org/10.1177/23409444211058179

http://hdl.handle.net/10138/340225

https://doi.org/10.1177/23409444211058179

cc_by_nc

publishedVersion

Downloaded from Helda, University of Helsinki institutional repository.

This is an electronic reprint of the original article.

This reprint may differ from the original in pagination and typographic detail.

Please cite the original version. 


\title{
In search of copassion: Creating a novel concept to promote re-enchantment at work
}

Business Research Quarterly 2022, Vol. 25(I) 82-97 (C) The Author(s) 2021 Article reuse guidelines: sagepub.com/journals-permissions DOI: $10.1177 / 23409444211058179$ journals.sagepub.com/home/brg

@SAGE

\author{
Anne Birgitta Pessi' (iD, Anna Martta Seppänen', \\ Jenni Spännäri' ${ }^{1 D}$, Henrietta Grönlund', Frank Martela² \\ and Miia Paakkanen'
}

\begin{abstract}
Re-enchantment taps well into the current zeitgeist: The rising focus on emotions and post-material values also in organizational context. Enchantment is deeply tied to socially generated emotions. Our aim is to develop the concept of copassion, referring to the process of responding to the positive emotion of a fellow human being. Concepts are crucial as they shape our understanding of the world. Our core claim is relating to our colleagues' positive emotions not only enables and maintains but also fosters enchantment at work. In this article, by laying the ground by discussing enchantment and the theoretical framework of intersubjectivity, we will link copassion to the physiological and evolutionary basis of humans, as well as explore its conceptual neighbors. Finally, we will discuss intersubjectivity, and particularly mutual recognition, as well as the inseparability of compassion and copassion in human experience at work, and its implications to the study of enchantment.
\end{abstract}

JEL CLASSIFICATION: MI4 Corporate Culture, Diversity, Social Responsibility

\section{Keywords}

Enchantment, re-enchantment, compassion, workplaces, business ethics, corporate social responsibility, copassion

\section{Introduction: intersubjective emotions in the process of enchantment}

Our era is marked by emphasis on emotions, looking at phenomena such as rise of populism, the return of tribalism, the resurgence of religion and spirituality, re-enchantment of science, and the return to craft, and the rise of post-material values (Suddaby et al., 2017). This also concerns workplaces and is noted in the rising narratives of meaning at work (e.g., Lysova et al., 2019; Martela \& Pessi, 2018) and workplace spirituality (e.g., Kolodinsky et al., 2008). The concept of enchantment - still regrettably seldom utilizedtaps very well into this zeitgeist. Disenchantment, as Weber (1946) in particular has analyzed, has been a major trend of Western societies throughout the last centuries, leading to the increased rationalization of life in general and work life in particular (pp. 129-139). Disenchantment and rationality cannot exist in the absence of mystery and enchantment (Suddaby et al., 2017, p. 286), and actually Weber too analyzed also on charisma and magic (Lee, 2010). Still, rationality has indeed been a key assumption of most organizational research (Strati, 1996), leading to the marginalization of emotions, aesthetics, and other more enchanted dimensions "disturbing" the rationality of work.

Workplaces and organizations, however, might never have been as deeply disenchanted as research has depicted

'Church and Social Studies, Faculty of Theology, University of Helsinki, Helsinki, Finland

${ }^{2}$ Aalto University, Espoo, Finland

Corresponding author:

Anne Birgitta Pessi, Church and Social Studies, Faculty of Theology, University of Helsinki, P.O. Box 4 (Vuorikatu 3), 00014 Helsinki,

Finland.

Email: anne.b.pessi@helsinki.fi 
(Boje \& Baskin, 2011). Inviting wonder (Carlsen et al., 2017; Carlsen \& Sandelands, 2015), generativity (Carlsen \& Dutton, 2011), and even humor into organizations (Välikangas \& Sevón, 2010) has pointed to its salience at work. Enchantment reaches beyond phenomena such as well-being or engagement at work, by connecting to larger frameworks for meaning in the life of individuals or communities and by transcending the boundaries between individuals and teams/organizations (Bell et al., 2020; Bennett, 2001, 2010). These dimensions have always been present at work. Thus, the current re-enchantment of work arises more strongly from a shift of focus in management research and managerial practice than from reappearance of enchantment at work per se. There has always been a powerful countertendency to fill the vacuum left by departed convictions (Carlyle, 1834/1991; Landy \& Saler, 2009). That is, humans are and have always been directed not only to ratio but also to enchantment and mystery (e.g., Carlsen \& Sandelands, 2015). Emotions, ethics, and much of what makes humanity interesting is inherently nonrational (Suddaby et al., 2017, p. 294). Thus, one could say: Humans and humanity are fundamentally enchantment oriented. Growing academic acknowledgment on enchantment is much called for. We aim to contribute to this need by creating a novel concept related to responding to positive emotions: copassion.

The concept of enchantment has been utilized sometimes rather narrowly, to refer to, for instance, the power of arts, aesthetics, and spirituality (Graham, 2007). The more applicable definitions of enchantment better compact the above-noted ethos of today-definitions such as "interior world of memory and reflection on the character, essence and authenticity of social structures" (Suddaby et al., 2017, p. 294). Even more precisely, enchantment refers to the feeling of being connected in an affirmative way to existence. It fundamentally entails concern for the other and appreciation for the other (Bennett, 2001, p. 156). Enchantment is thus deeply tied to both the sense of intersubjectivity and to relationally, socially generated emotions, also at work. This is exactly the viewpoint on enchantment of this article: We focus on emotions in intersubjective relations of workplaces. That is, responding to colleagues' emotions is the process of enchantment at workplaces that are intrigued by, intersubjectivity being our theoretical framework. As is illustrated in more detail in the next section, the aim of this article is to lay foundations and develop the concept of copassion.

\section{Toward a novel concept}

Our evolutionary basic nature makes human existence intersubjective (Tomasello, 1999), and the need for human relationship is one of our most fundamental motivations (Baumeister \& Leary, 1995; Deci \& Ryan, 2000). Furthermore, in order to flourish, we humans need shared positive emotions and positive recognition from fellow human beings (Ricoeur, 2004), such as colleagues at work. Our contribution to the re-enchantment of work in this article is to highlight one particularly interesting dimension of intersubjectivity that has thus far not received the research attention it deserves: emotions.

As humans, we are deeply emotional beings - even in seemingly rational dimensions such as decision-making (Kahneman, 2011). The crucial role of emotions at work is nowadays widely acknowledged (Ashforth \& Humphrey, 1995; Xanthopoulou et al., 2018; Zapf et al., 2021), with an increasing amount of research focusing on the interpersonal dynamics that determine the emotional atmosphere of the organization, through for example, emotional contagion (Barsade, 2002; Bono \& Ilies, 2006), high-quality connections at work (Dutton \& Heaphy, 2003), sense of psychological safety (Edmondson \& Lei, 2014; Frazier et al., 2017), interpersonal capitalization (Hadley, 2014), prosocial motivations (Grant, 2008a, 2008b), and the role of emotions, such as fear, in organizational performance (Vuori \& Huy, 2016). A key part of such emotional dynamics is how employees respond to the emotions of each other. Much research focus has been devoted to how to react in a supportive and compassionate way to the suffering of colleagues (e.g., Dutton et al., 2006; Lilius et al., 2011). However, how to respond to others' joy and positive emotions has thus far not received the research attention it deserves. For example, Ganegoda and Bordia (2019, p. 776) note that "no organizational research to date has looked at such positive response to coworkers' positive experiences." This is our particular take on emotions at work: the positive ones.

To participate in filling this lacuna of research, we propose that a new concept is needed: copassion. The related concept, compassion, refers to responding to the pain of other, and it has been much researched at work. It has been proven that compassion is a powerful force promoting better workplaces - for example through healthier working culture (Maitlis \& Ozcelik, 2004) and internal relations (Kettunen, 2018), work-life balance (e.g., de Bloom et al., 2015), and engagement and well-being (Hakanen \& Van Dierendonck, 2011) - and it can be cultivated in organizations (Paakkanen et al., 2020).

To follow the suit of compassion, copassion refers to the process of responding to the positive emotions of the other. As we will argue, copassion is an intersubjective process involving the noticing of other's joy, leading to the motivation to share this emotion, and even increase it, through actions that demonstrate to the other that one feels with them and shares their joy. We argue that copassion is important part of re-enchantment of work, as a crucial dimension of enchantment is humans intersubjectively relating to each other, in both negative and positive emotions. Indeed, it is crushing to go through a loss and carry great sadness without, also at our workplace, anyone 


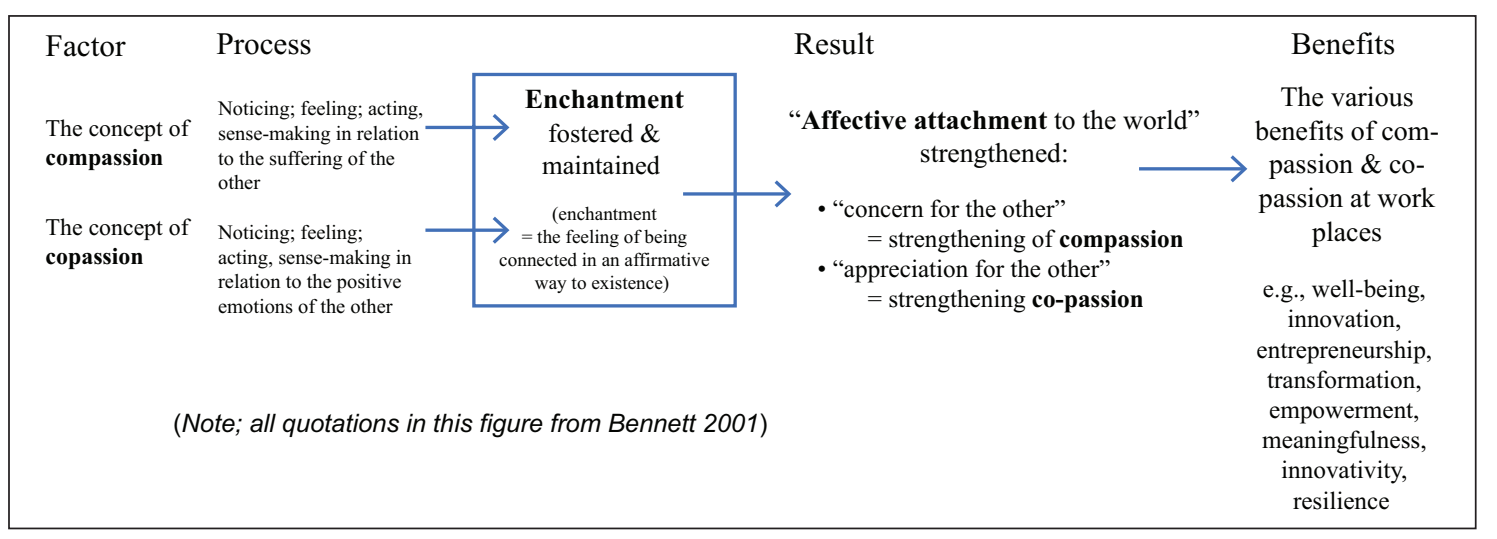

Figure I. The constellation of our study: factors and processes of compassion and copassion fostering enhancement at work.

noticing or reacting; we all need compassion. Empathizing in other person's pain and misery is a fundamental part of human intersubjectivity (Varga \& Gallagher, 2011; Zlatev et al., 2008). However, it is equally crushing to succeed at work and be happy about it — without anyone taking notice. And as we illustrate below, concepts enable us to better notice, acknowledge, and to intersubjective communicate matters in the everyday life.

Accordingly, we argue that examining copassion is important for research on intersubjectivity and shared emotions in organization. Along the core expression of enchantment by Bennett (2001), we are intrigued by being connected and by attachment, concern for the other, and appreciation for the other. Accordingly, we argue that relating to our colleagues' positive and negative emotions not only enables and maintains but also fosters enchantment at work.

Workplace is one core context that has for too long and too strongly been considered an arena of-if not exclusively, mainly - ratio, not emotions. Organizations have responded to the requirements of highly competitive global business contexts with intensified rationalization of organizational practices (Meyer et al., 2006, pp. 258-265). This strategy has, nevertheless, lead to dehumanization of working life (Meyer et al., 2006, p. 262), whose consequences are now visible in the indicators of quality of working life. For instance, the felt pressure to be constantly available challenges work-life balance and recovery (Barber et al., 2019). Symptomatically, one fourth of Europeans feel that work affects their health negatively (Eurofound, 2017). Thus, rationalization does not result in its explicit targets, more productive and efficient work - quite the opposite. As Guest (2017) has argued, this paradox points out the need to re-think how organizations are led. We argue that emphasizing the importance of emotions at work is an essential part of the re-thinking that Guest calls for.

As a counterforce to the over-rationalization of organizational thinking, several scholars have ventured in the realm of enchantment at work-using perspectives like generative dynamics in organizations (e.g., Cameron et al., 2003). This acknowledgment invites scholars to approach workplaces as places of wonder where both employees and managers are able to affect their work and find meaning in it (Boje \& Baskin, 2011; Endrissat et al., 2015). Copassion, as affirmative responding to colleagues' positive emotions, finds its place particularly in Bennett's (2001) framework of the result of enchantment where the focus is on the strengthening of affective attachment to the world through "appreciation for the other," in contrast to compassion coming closer to Bennett's (2001) "concern for the other."

Hence, we aspire to explore the possibility of a concept to grasp the phenomenon of empathizing and responding to positive experiences of joy and excitement of another person. In a preliminary manner, we indeed call this phenomenon copassion, to follow the suit of the concept of compassion. Copassion - similarly as compassion-is a process of enchantment at work. Furthermore, the concept of copassion is a pivotal factor in this process, as illustrated by Figure 1 .

Thus, the aim of our article is to lay foundations and develop the concept of copassion, utilizing the concept of compassion as our starting point. What does the concept of copassion refer to? What are its roots? How does copassion relate to the concept of compassion and to other neighboring concepts, and what might copassion look like in practice?

Next, we will start by exploring the relation of compassion and copassion and move on to tackle the cruciality of concepts. Then, we will proceed to laying the ground of our novel concept by framing with the philosophical framework of intersubjectivity, and in particular mutual recognition. This philosophical section does not aim at over-arching conceptual analysis per se, but at exploration of the enrichment to our perceptions that copassion brings for holistic interpersonal encounters, also at workplaces. We will then link copassion to the physiological and evolutionary basis of humans, as well as explore its conceptual neighbors. Finally, we will return and further discuss 
our framework of intersubjectivity, especially at work: The inseparability of compassion and copassion in human experience and the meaning of copassion as intersubjectivity in our everyday lives and well-being of our society.

\section{Defining copassion}

As noted above, to arrive at a definition of copassion at work, we need to start by looking at how compassion has been defined. Dutton et al. (2014, p. 277) define compassion as "an interpersonal process involving the noticing, feeling, sensemaking, and acting that alleviates the suffering of another person." There are indeed three steps in the process of compassion - noticing-feeling-acting - that are in constant interaction with each other, as well as a subprocess of sensemaking, which stands for the interpretation of the situation and its unfolding in all three steps. We cannot notice, nor feel, nor act with others without the process of intersubjective sensemaking.

Compassion thus starts with noticing: We need to become aware of the other's suffering in order to be able to react to it. Do we notice the pain and suffering of another? Do we notice, for instance, if a colleague is particularly quiet one day? Similarly, we can ask: do we notice if someone is in joy and in excitement? Sometimes the cues of someone experiencing suffering or joy are clear and at times they are ambiguous. Sometimes noticing them, for example, at work, is affected by our stress and hurry or the emotional rules in effect at the workplace. Understanding these, we may aim to deliberately pay more conscious attention to the different kinds of cues in our environment.

Noticing, however, is not enough for compassion-nor for copassion. We need to be moved by the other's suffering and feel empathic concern (Batson et al., 1991, 1997a, 1997b) for the other. Indeed, compassion is not simply the "sharing of another person's emotional state," but the "core relational theme" of compassion is "being moved by another's suffering and wanting to help" (Lazarus, 1991, p. 289). Similarly, Singer and Klimecki (2014, p. 875) emphasize that compassion is about "feelings of warmth, concern and care for the other, as well as a strong motivation to improve the other's wellbeing." Crucially, then, compassion involves a motivational component, a willingness to alleviate the suffering of the other. Similarly, copassion needs to include emotional empathizing with the other and the motivational component of wanting to participate in someone's joy in action, of wanting to show that "I am happy with you and for you."

Finally, the process of compassion involves action. In other words, concrete behaviors that "are intended to reduce or remedy the sufferer's pain" (Dutton et al., 2014, p. 284). This can involve a variety of different responses, ranging from being present and listening your colleague, to planned and elaborate actions that aim to provide targeted solutions to the kind of suffering that the sufferer is experiencing. For our intersubjective interaction, feeling with or empathizing with one another is not sufficient, but we also need to act for and with the other, in sorrow and in joy.

Compassion is in all of its three steps also about interpretation (Dutton et al., 2014). Thus, it always includes the sub-process of sensemaking. By taking a mindful distance to the interpretations we make, we can evaluate and shape our ways of interpreting, and thereby influence also the prerequisites of compassion, and copassion too. In practice, when something unexpected happens, we attempt to allocate meaning to it. We automatically arrange the events into a kind of a storyline, with a beginning, middle, and an end. We easily aim to give disconnected events a unifying meaning to help us decide how to act. For example, by verbalizing our interpretation, we may be better able to choose interpretations that more likely lead to actions.

All in all, copassion - to follow the suit of the definition of compassion (see, above, Dutton et al., 2014, p. 277) - can be defined in detail as an interpersonal process - or to verbalize it with our theoretical framework of intersubjectivity - an intersubjective process involving (1) the noticing of the other's positive emotion; (2) feeling with the other, sharing their positive emotion, and being motivated to increase their positive emotion; (3) sensemaking of the positive emotion of the other; and (4) showing in action to the other person that one feels with and for her or him, with the aim and wish to strengthen her or his positive emotion. To make this a bit more compact, copassion is an intersubjective process involving the noticing, feeling, sensemaking, and acting to share and to strengthen others' positive emotions.

In short, copassion is the process of responding to the positive emotions of a fellow human being. In this definition, the verb "responding" stems from the use of that verb in connection to compassion as a response to others' suffering (see, for example, Post et al., 2002). Joy as an example of positive emotional experiences, on the contrary, represents the "opposite" to compassionate response to pain and suffering. By a fellow human being, we refer to the intersubjective nature of copassion and to the acknowledgment of shared humanity in all our affective experiences.

Defining compassion leads us to ask: Is copassion possible for all humans? Are we all capable of it? The capability of and orientation toward enchantment and also toward compassion are considered a part of human condition (on enchantment, for example, Carlsen \& Sandelands, 2015; on compassion, for example, Marsh, 2016; Wilson, 2016). Already little children are not only egoistic but also able and inclined to both help others. And they are drawn to and fascinated by not only ratio but also enchantment. Our initial thinking is that copassion is a similar orientation in humans. That is, already little children may rejoice in other's joys. To utilize our definition of copassion we may state: Children are capable of noticing and feeling with the positive emotions of, for example, their parent or a friend, and to act to strengthen others' positive emotions, by, for 
instance, smiling with the other person. Such orientationwe believe-does not vanish by aging. Motivation for copassion, as for all behavior, is of course multifaceted and varies from one situation to another. We are never pure altruists or egoists.

However, copassion may also be linked to moral development; it could well be that it is more connected to higher level moral development and to certain type of moral socialization (e.g., Kohlberg, 1958, 1984; Turiel, 2002). This issue, however, has not yet been explored, and it lies also out of the scope of this article due to space limitation.

\section{Cruciality of concepts}

What is needed for the process of relating to fellow human's pain to take place toward fostering enchantment is not only compassion but also the concept of compassion. Too often in empirical research, we forget the power of words and concepts. They are pivotal factors for any process to take place. Concepts play a crucial role not only in verbalizing about - and in - the world but also in experiencing the world, such as a workplace. Concepts shape our view and understanding of the world. We are more likely to notice the things we can describe in words (ElderVass, 2012). Words affect our experiences too: More nuanced vocabulary to describe our experiences may help make our existence feel richer (Lomas, 2016). Humans have naturally been compassionate long before any research saw the light of day. But without an established concept, phenomena are more difficult to discuss and research, and are easily left unnoticed. Also, their positive consequences are left unrealized and unfacilitated, if we are unable to identify and talk about them. Words matter.

Concepts are core factors also in the processes of enchantment. Language is a powerful form of enchantment that remains largely unexplored in institutional processes in organizational and management studies. All transformations and change processes too take place with and through language in workplaces (Suddaby et al., 2017, pp. 293-294). Language is central to the formation of our personal identity and through language we humans organize our existence (Ricoeur, 2004; Venema, 2000). Moreover, the everyday language of organizations needs to be considered in order to battle against the dehumanizing tendencies of current organizations. An example of the power of words regarding the preconditions of enchanted work is the notion of Human Resources Management: referring to humans as resources of work is not merely a neutral choice of words. It embodies in the instrumentalizing management practices (Islam, 2012). We will elaborate further the notion of the importance of language in the section on the philosophical framework.

For responding to colleagues' pain, as a process of enchantment, we already have a concept, compassion, as noted above. The phenomenon has been analyzed under other conceptualizations too, such as altruism, helping, empathy, empathic concern, and pro-sociality. Researchers have investigated in several studies how compassionate reaction takes place and is facilitated in social settings, such as work (Dutton et al., 2014). Dutton et al. (2014), for instance, define compassion as an interpersonal process involving the noticing, feeling, sensemaking, and acting that alleviates the suffering of another person. But concerning responding —or failing to respond to - other's joy and excitement at work, what word would we use? We do not have a concept in English language, either in academic or non-academic discourse, for relating to fellow human being's positive emotions. It has actually been more conceptualized and promoted rather by religious communities, as we will later illustrate.

Within the last two decades, compassion has risen to be the focus of special interest, for example within psychology and organizational research, because it has been associated with many positive impacts such as increased social connectedness and positive affect (Fredrickson et al., 2008), and improved cooperation (Dutton et al., 2007) and trust (Clark, 1987). The roots of conceptualizing compassion are, however, both deep and wide in the history of both Eastern and Western religious meaning systems, as well as that of philosophy (e.g., Aronson, 1980; Davies, 2003; Scheler, 1923/2008; Smith, 1984). Interestingly, we can also trace some roots of copassion too. Within Buddhism, compassion (karuna) is, in fact, only one of four important virtues or attitudes, thought to be strengthened through meditation practice. Another important virtue is sympathetic joy (mudita), which is defined as joy in the happiness of another, instead of envy or dislike (Aronson, 1980; Makransky, 2012). Out of the four Buddhist virtues, sympathetic joy comes closest to copassion. The African ubuntu (literally translated as humanity) is a religiously rooted concept related to compassion, but not explicitly connected with suffering. For example, in addition to compassion, it refers to reciprocity, dignity, harmony, and humanity, which aim for building and maintaining the community by means of fairness and reciprocal caring (Du Plooy, 2014; Ndlovu, 2016; B. Nussbaum, 2003).

The Hebrew language has a concept that resembles copassion, the noun firgun, originally derived from Yiddish. This is, apart from a single word, also an Israeli cultural concept for which it is difficult to find a match in other languages: complete selflessness characterizes the way of relating to the success of others that is depicted by the concept of firgun (Katriel, 1993). Moreover, also in philosophy, phenomenologist Max Scheler (1923/2008) has written about Mitfreud, which translates quite literally to what we mean by copassion. Furthermore, the Latin origin of compassion (lat com + pati; compare English "passion") actually does not refer only to responding the other person's misery but strong emotions in general, thus possible positive ones too. However, compassion has a clear 
reference in English to only suffering and pain. All in all, there are indeed disperse deposits of copassion, but for some reason none of the concepts has gained a position in everyday nor academic discourse.

Recently, researchers of empathy have coined the term positive empathy to describe the understanding of and sharing of positive feelings of others (Morelli et al., 2015). Positive empathy is a critical part of copassion, as we will explain later on in the paper. It is not, however, sufficient to cover the entire interpersonal process of copassion. Rather, much like empathic concern in the process of compassion, positive empathy stands for one step in the process of copassion, albeit a crucial one.

\section{Theoretical framework: copassion as an expression of human intersubjectivity}

Even if concept has lacked, copassion is rather easy to recognize intuitively as a core issue of everyday human experience, exactly like compassion too. For example, is your spouse happy for you and with you when you are happy? Do your colleagues rejoice in your successes? How would it feel if you at work share about your excitement regarding an interesting project-and nobody responds? In healthy social relationships, copassion seems to be an integral part of the nature and definition of such a relationship. The lack of it, in turn, easily penetrates our self-relation: my joys and passions are irrelevant to my community - am I irrelevant too? One's experience of self-esteem is challenged. This everyday observation on the great importance of copassion points back to a more fundamental origin of phenomena like compassion and copassion: human intersubjectivity. The origins of healthy self-relation lie in intersubjective, reciprocal interactions, which may embody as such emotion-laden interaction sequences like compassion and copassion (Honneth, 1995; Ricoeur, 2004). Thus, to lay the philosophical foundations to our elaboration of copassion, we sketch our framework through the concepts of intersubjectivity, and in particular, mutual recognition.

An intersubjective view of humanity emphasizes that human identity and action are intertwined with other people in a fundamental way. At its most reduced definition, intersubjectivity can be taken to refer to the phenomenon of sharing experiential content among a plurality of subjects, but there are various definitions, understandings, and approaches to intersubjectivity in various disciplines (Zlatev et al., 2008). In this article, we follow the lead of several philosophical accounts of intersubjectivity which go beyond the notion of sharing experiential content: intersubjectivity holds a fundamental importance to our understanding of objective reality, to the construction of personal identity, and to our perception other people qua persons and the following moral obligations (Bradfield, 2013; Crossley, 1996; Honneth, 1995; Ricoeur, 2004).
An intersubjective view of humanity may seem selfevident. However, the assumption behind, for instance, the mainstream of economic thinking has long been - and in part still are-influenced by the idea that human rationality and maximization of personal utility characterize humanity and human action in a more fundamental way than the inclination toward others (Persky, 1995). This "homo economicus" anthropology of neoclassical economics has nevertheless been challenged. Scholars have pinpointed that homo economicus does not stand a critical ontological analysis and ignores the processual and open nature of social reality (Davis, 2012; Lawson, 2015).

Besides its theoretical shortcomings, homo economicus conception has also ethically questionable consequences. Several empirical studies have suggested that during business education, which is infused with neoclassical theory, business students - future managers in the making - learn to perceive the characteristics of homo economicus as the ideal characteristics of a person. They start to adapt their own behavior according to that ideal (Lynnette \& Davis, 2004; Racko, 2019; Wang et al., 2011). Thus, homo economicus conception, for one, contributes to the dehumanization of working life (Ritzer, 2005) by legitimizing and even idealizing self-interested behavior. For homo economicus, other people are fundamentally instruments of his or her own success, not ends in themselves. As mentioned earlier, the current practice of human resource management (HRM) exhibits this same instrumentalizing tendency (Greenwood, 2002; Guest, 2017; Islam, 2012).

It is a matter of dispute whether self-interest is ethically questionable. For instance, business ethics and corporate social responsibility literature hosts a broad discussion on whether enlightened self-interest is a strong enough justification for corporate responsibility (e.g., Cragg, 2012). From consequentialist moral-philosophical perspective, self-interest might indeed not be morally faulty; for consequentialist, moral evaluation consequences are more important than intentions or agent's moral character. We, nevertheless, do not attach ourself here to consequentialist but to Kantian basic moral-philosophical premises. From Kantian perspective, the source of our moral obligations to others is the personhood of each human being. The personhood is the quality inherent in every human being that grounds the moral obligation to treat everyone as ends-inthemselves, not as a means to one's own ends (Korsgaard, 1996). Thus, when we later use expressions personhood or treating people qua persons, we refer to personhood/person as a moral, not a psychological concept. In Kantian sense, self-interest is morally questionable precisely because it ignores the personhood of others.

The philosophical-theoretical and ethical challenges of homo economicus pinpoint the importance of grounding our notion of copassion as a process of enchantment at work in the intersubjective view of humanity. Our starting point is Paul Ricoeur's (2004) take on intersubjectivity, as 
it is presented in his last monograph "The course of recognition" (Parcours de la reconnaissance), building on his earlier works. For Ricoeur, the fundamental orientation toward other is implicated in human agency. For instance, for Ricoeur, the capacity to speak is a fundamental key of being human, and speech is always directed at another person. Speech, for one, manifests our orientation toward alterity (Ricoeur, 2004, pp. 143-146; 363).

However, this orientation does not mean that we would be able to fully understand the other. The other person is a mystery, a source of enchantment. For Ricoeur, the otherness of other is extreme and irreducible: I cannot ever grasp the lived experience (fr. le vecu) of the other and see the world from his or her perspective. Nevertheless, in fleeing moments, this gap between me and the other can be transcended in intersubjective experiences of mutuality (Ricoeur, 2004, pp. 227238). A business leader and a stay-at-home mom may, for instance, attain a reciprocal experience of esteem and appreciation even if their accomplishments are from completely different arenas of social life. Intersubjectivity, for Ricoeur (2004), is about being able to "compare the incomparable" (p. 238). The tension of me and other exist, but it can be momentarily overcome.

We have already in the previous section referred to the importance of language and concepts in integrating elements of enchantment to contemporary organizations. The centrality of language to our personal identity and social life is a theme that transcends Ricoeur's philosophical career (Venema, 2000). Ricoeur's interest was mainly in forms of language longer than separate words: in metaphors and metaphoric language (e.g., Ricoeur, 1975) and later on in narratives (e.g., Ricoeur, 1983). If we apply Ricoeurian thinking to the analysis of the concept of copassion as an antecedent of re-enchantment, it is not the word per se which is the antecedent. The antecedent is a narrative, or rather, narratives that the concept of copassion allows us to tell about ourselves and others in our work organizations. Copassion as a concept opens up a possibility to coin events in a way that is not possible without it: it provides a model for the emplotment, a term used by Paul Ricoeur to describe the act of organizing a series of events into a narrative with a plot (Ricoeur, 1983). Copassion is a story of noticing the other's joy and excitement, responding to that with empathetic feeling and acting upon it. The existence of such concept in our vocabulary and the understanding of it as a dynamic series of events facilitates grasping, narrating, and documenting in textual forms events in our work organizations which would otherwise escape our attention.

Ricoeur's take on intersubjectivity and mutuality opens an interesting path for the exploration of the ethical dimensions of copassion. Copassion acts as a counterforce to the ethically unsustainable instrumentalizing and dehumanizing tendencies of contemporary organizations. Copassion highlights the significance of a colleague's experience of joy or enthusiasm in its own right, not the instrumental value of his or her joy in relation to, for example, the competitiveness of the organization. It, then, materializes the Kantian moral obligation of orienting toward others as persons who merit to be treated as ends-in-themselves. Ricoeur connects the notion of intersubjectivity with the notion of mutual recognition - intersubjectivity being the condition of it (Ricoeur, 2004, p. 363). By mutual recognition, Ricoeur-similarly as Axel Honneth (1995) - refers to reciprocal intercourses in which one orients toward another qua person, through positive attributes and by acknowledging his or her personhood. Mutual recognition is, through its definition, positive and normative: the more mutual recognition the world exhibits, the better.

Mutual recognition consists of three levels, derived from Hegel's thinking on Anerkennung: (1) Recognition as an affective relation to a close person (recognition as love), which, for instance, is typical to the caring relation of an infant and a primary caretaker. (2) Recognition of each person as the possessor of universal rights (juridical recognition). A historical example of the lack of such recognition would be, for instance, the African Americans and their lack of full civil rights. (3) Recognition as respect for the individual value of each person in a community (recognition as social esteem). An everyday example of such recognition could be, for example, receiving public praise at workplace (Honneth, 1995; Ricoeur, 2004).

The wish to be granted recognition in mutual relationships is a fundamental human need, and from this notion arises the normative core of contemporary theories of recognitions: as many subjects as possible should be able to receive recognition, and society's institutions should be organized to support this development (Varga \& Gallagher, 2011; Zurn, 2010). The denial of recognition, in turn, is an impetus of struggles for recognition, which orient the developments of institutions and societies (Honneth, 1995). A contemporary example of such struggle in organizational context is the struggle of workers of platform-mediated work for the recognition of their rights to decent labor conditions (Mattila, 2019). Such struggle would exhibit the second level of recognition, recognition as justice.

However, the focal notion of recognition theory in its Honnethian and Ricoeurian form is that lack of recognition as the lack of rights is only one embodiment of the experiences of injustice. Different social pathologies, such as denial of social esteem at work place, are also to be considered as forms of injustice, that political-ethical theories need to address (for an examination of the relation of Honneth's theory of recognition and Habermas' intersubjectivist paradigm in critical theory cf. Renault, 2010). As an example, concerning different forms of injustice in work organization, we can take the case of Finnish working life. In Finland, as in general in the Nordic countries, recognition in the juridical sense is highly prevalent in the working life (Eurofound, 2017). Another source of injustice must, 
however, exist, and the consequences of the dehumanization of working life being visible: work-related mental health issues have increased drastically and over $50 \%$ of employees have had experiences of cynicism and chronic exhaustion at work (Keyriläinen, 2020). We propose that it is, at least to some extent, the lack of recognition of employees qua persons which is a focal source of such challenges.

Our suggestion is that copassion can be discussed and embedded in the framework of mutual recognition in order to ground the ethical importance of the concept copassion in the current disenchanted world of work. Copassion, then, should be regarded as one of the recognitive attitudes. In the analysis of Ikäheimo and Laitinen (2007), the aforementioned three levels of recognition are recognitive attitudes which are different ways of taking someone as a person, that is, as an individual who can make moral claims on me (Ikäheimo \& Laitinen, 2007, p. 38). Each form of mutual, intersubjective recognition promotes an aspect of positive self-relation (Honneth, 1995, p. 129). Attaining recognition as love leads to basic self-confidence, that is, seeing oneself as a person whose needs are legitimate and who is worthy of being cared for (Ricoeur, 2004, pp. 276-286).

It might seem intuitive that out of the three levels of recognition or three recognitive attitudes copassion would have the closest affinity with recognition as love. We, nevertheless, suggest that copassion is closer to recognition as social esteem (mutual experience), which reflects to one's selfesteem (aspect of self-relation), the experience of being a valuable member of a community (Ricoeur, 2004, pp. 294 314). Joy and excitement, the triggers of copassion, are not expressions of needs, quite the contrary. They are emotionally charged expressions of experiences of having, encountering, or achieving something which is valuable to me personally, something that I esteem. We theorize that if we are to perceive copassion as a recognitive attitude, it has in communities a close affinity with recognition as social esteem and, thus, it purports to sense of self-esteem.

In sum, theorizing copassion in the philosophical framework of Ricoeur's idea of intersubjective recognition allows us to grasp three focal points. First, it illustrates the intersubjective origin of compassion and copassion and, hence, their fundamental importance in counterbalancing the tendency of treating people as mere resources of the pursuit of profit. Second, it allows us to explicate the importance of the existence of a concept copassion to the aim of re-enchanting working life: the concept opens up the possibility to narrate the stories of, not just productivity and efficiency, but also of responding to the joys and passions of my colleagues qua persons, not qua resources of work or instruments of my success.

Third, it facilitates grasping the ethical importance of copassion. Copassion is directed at joy and excitement as parts of personhood, and in that sense, it differs from compassion which is directed at needs as parts of personhood. The lack of copassion undermines person's self-esteem.
For a work organization, the lack of copassion is an ethical shortcoming: it is a failure to recognize the intrinsic value of the emotions of employees. Recognition theory has also in its more classical forms (Rössler, 2007) been applied to and developed through the analysis of labor, and writers such as Islam (2012) and Pless and Maak (2004) have ignited the discussion in the applied business research context. Our analysis of copassion in the framework of philosophical recognition is tentative, but it opens up interesting paths toward more sustainable work. Which kinds of struggles for recognition the lack of copassion leads? Which dysfunctionalities of current organization could be traced back to the lack of copassion? To what extent copassion is a purely intersubjective occurrence and to what extent it could or should be institutionally mediated? These questions remain to be analyzed in future research.

Finally, where, then, is the enchantment of copassion as a recognitive attitude? The answer points back to Ricoeur's notion of the otherness of the other. We live our life among people whose importance to ourselves is fundamental, but who, nevertheless always remain mysteries to us. In contrast to Honneth, who concerned about the struggles for recognition, Ricoeur is interested to know, how do we identify the true moments of successful mutual recognition (Ricoeur, 2004, p. 276, 318). He discusses these moments as gifts - echoing Bennett's (2001) definition of enchantment as being "under the momentary impression that the natural and cultural world offers gifts" (p. 156). Ricoeur goes on to summarize mutual recognition: "I am here speaking about 'a clearing' in the forest of perplexities" (Ricoeur, 2004, p. 355). We see the launching of the concept of copassion to organizational research as an opportunity to create these gift-like clearings in the perplexing context of contemporary organizations.

\section{Intersubjectivity grounded in the physiological and evolutionary basis of humans}

There is a deep physiological and evolutionary basis for all this. In line with modern evolutionary research about human prosocial dispositions (Brown \& Brown, 2006), both psychological research (Batson et al., 1997a, 1997b, 2009) and organizational research (Grant, 2008a, 2008b) have demonstrated how prosocial motivations are deeply rooted in human nature. The foundation of intersubjective human existence lies in our biological nature. We are social animals and it is well established that humans have a fundamental motivation or a need to be in close relationships defined by mutual affection and care (Baumeister \& Leary, 1995; Deci \& Ryan, 2000). Our emotional capacity of affective proximity to identify with a caretaker is the prerequisite of all empathy and compassion (Tomasello, 1999).

Moreover, we not only need to feel cared, we also have an inbuilt tendency to care about each other, especially 
those close to us. This tendency to care about others has evolved from the mammalian tendency to care for one's offspring. In mammalian species, the survival of the offspring is dependent on their parents (or at least one parent) providing them with continuous care and remaining attentive to cues that their offspring's well-being is threatened (Marsh, 2016). Furthermore, in species like humans that have traditionally lived in small, highly interdependent groups, this capacity for caring has extended to include the offspring of others, one's close relatives and other members of one's group. Kin selection (Hamilton, 1964) - by helping those genetically related to us we help our types of genes to spread — and reciprocal altruism (Trivers, 1971) helping those who later help us-benefit both parties. They are the key evolutionary mechanisms that explain how such tendencies for prosocial behavior have increased the evolutionary fitness of humans, and the mechanisms themselves have thus been promoted by evolution. To conclude, research from various fields illustrates that empathy, compassion, and an innate motivation to care about the wellness of others are parts of our psychological-biological makeup and make us most productive and resilient (e.g., de Waal, 2009; Wilson, 2016).

It has been proposed that emotional closeness serves as a proxy for both genetic relatedness (Korchmaros \& Kenny, 2001, 2006) and for the one who is likely to reciprocate (Brown \& Brown, 2006). In other words, the stronger the social bond we feel we have with a fellow human being, the more likely it is on average that the other is genetically related and/or likely to reciprocate our favors. Accordingly, while indiscriminant helping of everyone wouldn't be a stable strategy in evolutionary sense (Brown \& Brown, 2006), the tendency to care about and do good things to those we feel are close to us and with whom we have a strong social bond is most likely a strategy with ultimate evolutionary benefits. Indeed, research has shown that various forms of emotional or social closeness toward the other tend to increase our willingness to help that person (Korchmaros \& Kenny, 2001; Levine et al., 2005). The roots of human caring, compassion, and copassion are thus found in the fact that in human beings the mammalian capacity to care for one's offspring has expanded into a capacity to care for the wellness of those that we feel as being close to us and identifiable to us - and not only our own relatives. And such actions of compassion and copassion then further maintain and promote our intersubjective closeness with them.

Furthermore, our embodied orientation and capabilities for intersubjective interaction are not only crucial for babies but for adults too. Microanalysis of gestures, gazes, postures, facial expressions, and their synchronization between people interacting with each other illustrates the depth of intersubjectivity in us (e.g., Lindblom, 2007; Niedenthal et al., 2005) and for example our capacity to biologically share positive emotions, or in other words, experience positivity resonance with another person (Fredrickson, 2013; Fredrickson \& Joiner, 2002). We are physically, cognitively, and affectively deeply tuned to each other and to our interaction, both in positive and negative moments in life.

Primary intersubjectivity is a fundamental part of a larger account of social cognition (Varga \& Gallagher, 2011, p. 254). Together, we experience the world in a form that has been called "participatory sense-making" (e.g., De Jaegher \& Di Paolo, 2007). These processes are equally active and essential in all contexts of social human life, including at work. They aim at building an experience of social connection - "the development of positive relationships with others in the social world" (Seppälä et al., 2013, p. 412). With our fundamental intersubjectivity, it is possible to make sense together of both success and adversity—at work and in general.

\section{Neighboring concepts of copassion: positive empathy, emphatic joy, and sympathetic joy}

We have now presented the intersubjective view of humanity that calls for a concept of sharing of and responding to other people's positive experiences. We have talked about the philosophical and the evolutionary history of intersubjectivity as well as discussed the roots of copassion by taking a look at some similar kinds of existing concepts present in other languages and religious cultures. We have then suggested a definition for copassion, following the definition of compassion. To better understand what copassion could be at work, as process of enchantment, let's also take a look at some existing concepts relating specifically to the suggested definition of copassion as an interpersonal process of responding to others' positive emotions and experiences. Namely, some concepts especially in psychology come somewhat close to the concept of copassion or may play a part in it while still being different from the concept of copassion as a whole. We wish to pay attention particularly to three such concepts: positive empathy, emphatic joy, and sympathetic joy.

First, positive empathy (Morelli et al., 2015) refers to understanding of and sharing of positive feelings of others. More specifically, it refers to "the ability to share, celebrate, and enjoy others' positive emotions" (Morelli et al., 2015, p. 57) and to "the positive affect elicited in people in response to their perception of the positive affect of another person" (Telle \& Pfister, 2015, p. 2). Sounds a lot like copassion. However, if we look at the concept more closely, we can see that it is an important part of the process of copassion, but not the same as copassion as whole. Positive empathy includes the word empathy. Empathy is most often associated with noticing or experiencing of another's feelings and thoughts. Another term that has been used is mentalizing, defined as "our ability to read the mental states of other agents" (Frith \& Frith, 2006, p. 531). 
In phenomenological framework, empathy is described as "a basic, irreducible, form of intentionality that is directed towards the experience of others" (Zahavi, 2010, p. 291; cf. also Englander \& Folkesson, 2014).

Empathy has been distinguished into two elements: affective and cognitive empathy. Affective empathy refers to the human capacity to share the feelings of others, and really feel what the other is feeling (Singer \& Klimecki, 2014). Sometimes it is simply referred to as empathy. For example, Hoffman (1981, p. 128) defines empathy as "a vicarious affective response to others, that is, an affective response appropriate to someone else's situation rather than one's own," and Singer and Lamm (2009) define it as "the ability to share the affective experiences of others" ( $p$. 81). Most technically, such affective empathy has been understood to involve four components: "(i) one is in an affective state; (ii) this state is isomorphic to another person's affective state; (iii) this state is elicited by the observation or imagination of another person's affective state; (iv) one knows that the other person is the source of one's own affective state" (De Vignemont \& Singer, 2006, p. 435). As the capacity to resonate with other's emotions, affective empathy takes place similarly both with positive and with negative emotions. In affective empathy, we both "share the experience of suffering," and "feel happy when we vicariously share the joy of others" (Singer \& Klimecki, 2014 , p. 875). Empathy is thus about feeling with the other, sharing the sadnesses and joys that the other is feeling.

Cognitive empathy, on the contrary, is a more cognitive effort to look at the world from the point of view of the other. It has been called perspective taking (Batson et al., 1997a). It is thus less about feeling what the other feels, and more about understanding how the other understands the world. Still it is worth noting that perspective taking is not just "cold" understanding, but has been consistently shown to increase the sense of empathic concern for the other, and our willingness to help the other (Batson et al., 1997a).

Positive empathy is what may follow from experiencing affective or cognitive empathy, as one comes to care for the other person's positive emotional experience (Paakkanen et al., 2020). As researchers into positive empathy suggest, it may lead to prosocial motivation and a subsequent prosocial behavior (Morelli et al., 2015; Telle \& Pfister, 2015). It is thus one facet of overall empathic concern (Paakkanen et al., 2020). Like in the process of compassion, as discussed earlier in the paper, empathic concern, however, is a critical step, but it does not stand for the entire process of responding to alleviate the pain and suffering of the other person. Similarly, positive empathy is a critical step in the process of responding to the positive emotions of the other person, but it does not cover the entire process. Furthermore, in the everyday, the connotation of "empathy" might more easily take one's thoughts to pain or suffering (even if positively encountering them) than does "passion" (in copassion) that is perhaps more easily connotated with joy and the positive, for instance, "being passionate about something." Here, we can again see the Latin roots, noted above.

Closely similar term, empathic joy (Batson et al., 1991), despite it referring to empathy and joy, doesn't quite mean the same as copassion either. Rather, empathic joy is the result of witnessing the fulfillment of the needs of a person who has needed help. It refers to the experience of relief and joy that follows, when someone witnesses a person in need of help receiving support. Here, we can see "empathy" referring to reacting to distress (see above, "empathy" vs "passion") (Batson et al., 1991). When it comes to copassion, the concept of empathic joy does not include the motivation to strengthen the other person's joy or actions to do that like copassion does.

Sympathetic joy (Aronson, 1980) was discussed earlier in connection with the Buddhist view of the four virtuous attitudes to life. The concept indeed stems from Buddhism and refers to sharing of joy and happiness like copassion does. In the Buddhist context, the purpose of the concept is to expand our understanding of the sources of happiness. Usually, we rejoice for the things we receive, but sympathetic joy emphasizes experiencing joy and happiness for the things others receive or have. Sympathetic joy, hence, refers to rejoicing in the joy of the other, without envy or resentment (Makransky, 2012). Thus, whereas empathic joy stands for the experience of joy following the witnessing of someone's need being fulfilled, sympathetic joy stands for rejoicing in someone's joy without any need of help having to be fulfilled.

Sympathetic joy thus refers to sharing of others' joy much like positive empathy does (see above, "positive empathy"). It does not, however, refer to an other-oriented motivation to strengthen it for the benefit of the other person (i.e., the third step of copassion). It doesn't seem to include a motivational step like copassion and compassion do, but it rather seems to refer to positive empathy (see above, "positive empathy"). Compared to positive empathy though, sympathetic joy doesn't exclude cognitive empathy, but would rather extend positive empathy to include both affective and cognitive empathic sharing of others' joys.

\section{Discussions: copassion playing a role in enchantment of work?}

Appreciation for the other and appreciative deeds-the core results of enchantment at work by Bennett (2001) definitely does not always need words. But words are never just words; concepts are crucial in noticing, feeling, acting toward or with a colleague, and making sense of the pains and joys of a colleague. Humans also need concepts in order to share narratives. Thus, in this article, following the definition of compassion, we have aimed to create a novel concept for praxis as well as for research: copassion. 
Copassion is about responding to the positive emotions of fellow human beings. Precisely, copassion can be defined as an intersubjective process involving the noticing, feeling, acting, and sensemaking, to share and to strengthen others' positive emotions. Copassion may at first glance seem like a positive, yet of less importance, little-sisterconcept of compassion. However, looking at it from the intersubjectivity perspective of mutual recognition, it actually grounds compassion. This is evident, we consider, in the everyday of work. For instance, if in a relationship there is no copassion, it definitively hinders compassion when pain and worries appear. Or if a workplace is managed by fear and an attitude of a zero-sum-game - instead of culture of sharing also the positive and being happy for the joys of the others - atmosphere and working culture are definitely not fertile for expressions of compassion. Copassion may indeed be needed for compassion. Furthermore, both are crucial for organizations to perform innovatively and strategically in business (Vuori \& Huy, 2016).

There is synergy between compassion and copassion. Especially in particularly meaningful human relationships, the two appear side by side: We share both our joys and our sorrows. As we are intersubjective beings, compassion and copassion exist - and should be explored - in a relationship with one another. The synergy of compassion and copassion resonates to the core of enchantment at work: by employing them both, we can enhance the feeling of being connected in an affirmative way to our existence. Indeed, copassion does not entail denying the negative or even focusing on the positive. Workplaces too are always full of spectrums of emotions. The positive may be found-or even strengthened - in the midst of deepest pain, and vice versa.

The positivity resonance with others, as noted above, plays an important role in promoting well-being, good relationships, and sense meaningfulness in human lives (e.g., Fredrickson, 2013; Fredrickson \& Joiner, 2002), all this for sure in synergy with enchantment too. For example, the longest and still ongoing study on happiness, the Harvard second-generation study of adult development, suggests that a satisfying social connection is a determinant factor in human happiness (Waldinger et al., 2014). Responding to and being heard in one's positive emotions plays an important role in enabling and creating an experience of trust, social connection, and psychological safety. They are all very much needed in today's working life; the quality of working life is deteriorating (Guest, 2017). Organizations have responded to the requirements of competitive global markets with intensified rationalization of organizational practices (Meyer et al., 2006, pp. 258-265). The norms of efficiency and productivity have resulted in dehumanization of working life (Meyer et al., 2006, p. 262), linked to impaired mental health at work (Becker et al., 2013) and, for instance, diminished work-life balance (Barber et al., 2019). One fourth of Europeans feel that work affects their health negatively (Eurofound, 2017). Also, increasing role diversification - and the consequent apprehension of employees qua roles not qua persons - threatens the integrity of personhood and the possibility to grasp the existential meanings of one's work (Kallinikos, 2003). All this threatens enchantment at work too- and underscores the urgency to invest in it.

The benefits of copassion do not limit themselves to organizations. Individuals, and the microcultures they form, influence and change social and societal contextssuch as organizations and even societies. The relationships between different levels of social life are always reciprocal. Copassion at the level of individuals, and the aspiration of individuals to copassionate cultures and norms, influence the microcultures of organizations and communities. As such, fostering copassion at different levels can even promote crucially beneficial societal and cultural phenomena such as generalized trust and social capital (see, for example, Grootaert \& Van Bastelar, 2002; Putnam, 2001).

Copassionate and compassionate cultures may be particularly central in the changes and challenges of our time such as digitalization, artificial intelligence, climate change, and global pandemics such as the COVID-19 (see, for example, Arntz et al., 2016; Frey \& Osborne, 2017; Hofmeyer et al., 2020; Pajarinen \& Rouvinen, 2014; World Economic Forum, 2016). Copassionate and compassionate cultures can alleviate uncertainty and anxiety and build ground for joint efforts to finding solutions. Human connection to others, including ability of perspective taking, is a proven key (e.g., Hoever et al., 2012) to unlocking diversity's potential concerning, such as team creativity at work and in business.

\section{Working forward: research and practice}

We have opened the floor to understanding what copassion is, yet much future exploration is needed - both in the context of workplaces, in business, and in general. To start, does copassion means responding to all positive emotions or only to some specific ones - and how they all illustrate enchantment? Related to that, copassion should also be explored in several cultural contexts (Bermant et al., 2011; Lomas, 2016) and within different organizations, businesses, and industries. To what extent the power of copassion to generate enchantment at workplaces is culturally oriented and biased, and to what extent universal? What kind of variation might there be among various types of workplaces and business sectors? Copassion also inspires ethical contemplation. To think about a colleague rejoicing about something that you think is ethically questionable, Can and should you be joyful in her or his joy? Further analysis of such dilemmas must also take morality and its development into account. Motivated by Kohlberg's $(1958,1984)$ academic classic on moral development one 
can ask, What kind of moral development and level of moral thinking might copassion require? And to what extent are humans oriented to intersubjective positivity resonance (e.g., Fredrickson, 2013; Fredrickson \& Joiner, 2002) and to helping each other (e.g., Levine et al., 2005; Tomasello, 1999) by nature - as well as to enchantment, by nature? How are these phenomena actually linked to each other? Fascinating academic work remains to be conducted.

There is also uncharted terrain for conceptual explorations of enchantment and copassion: How might they both conceptually and empirically function in languages and cultures in which it does not yet exist or are not widely know? How does enchantment theoretically and empirically relate to its neighboring concepts, such as elevation or self-transcendence. We have aimed to pursue a similar exploration in this article regarding copassion and its neighboring concepts. Furthermore, how might conceptual and empirical cross-constellations concerning, for instance, the interlinks between enchantment, copassion, and moral elevation take place at work?

Furthermore, we also call for research on how the process of copassion and its sub-processes function in practice in workplaces and their enchantment. Particularly, the element of actions (as a part of the four steps of noticing, feeling, sensemaking, acting) may be specifically fuzzy: What might it be in practice? And how to routinize it in the everyday, toward enchantment? Such further research would benefit developing survey measures for copassion-and even enchantment. Interdisciplinary empiricalphilosophical collaboration, as we have aimed to demonstrate in this article, might allow to enrich clarity on, for example, the relation of compassion and copassion to justice and fairness too (Lemberger \& LembergerTruelove, 2016; Shahzad \& Muller, 2016).

Further empirical research on copassion might be able to illuminate how recognitive attitudes materialize in everyday contexts, and how they are related to social and institutional spheres. Recognitive attitudes are pivotal in thinking about and working on enchantment at work, both concerning fostering concern for the other (e.g., compassion) and appreciation for the other (e.g., copassion) (Bennett, 2001). Such attitudes, in turn, impact individual and organizational performance as has been found in prior research (Dutton et al., 2007). They also shape the opportunities for business innovation, potentially strengthening the willpower to innovate (e.g., Goss, 2005).

There should not be a value notion of disenchantment being de facto bad and enchantment, or re-enchantment, de facto good. Also, Suddaby et al. (2017, p. 285) note that not all enchantment or re-enchantment is positive. In this article, we have focused on the positive, fruitful power of enchantment at work, and the role of the concept of copassion in it. Yet, further research can add more layers and nuances to our understanding - including debatable or ambiguous ones - on the power of copassion in promoting enchantment at work.

To conclude, the concept and the phenomenon of copassion concern our conception of the nature of human existence. This at first glance a theoretical issue is in fact an implicit principle that structures our choices in everyday life. How important we think that copassion is to human flourishment? To what extent do we want to promote the prerequisites of compassion and compassion? Do we prioritize intersubjective phenomena over self-interest and personal utility? And, for instance, on what grounds and on which topics, business leaders choose to focus on in their feedback?

All these questions reflect much wider issues too. Ethicists and critical organizational scholars have pointed out that the current practice of Human resources management approaches employees as material and financial resources, that is, as means to organizational ends, thus depriving them of their essential aspects, such as relationality and intersubjectivity (Greenwood, 2002; Islam, 2012; Kallinikos, 2003; M. C. Nussbaum, 2006; Pless \& Maak, 2004). Under these circumstances, how to be positively connected to work? How to be enchanted by work and at work with others?

Hence, as we have now developed the concept of copassion as a promoter of enchantment at work, it is not only important to emphasize the significance of emotions at work. We also point out the focal need to ground the concept of copassion in a different view of humanity than the one fostered by the current practice of HRM: Re-enchantment of work is not possible unless we base the conceptual constructs and practice of management to an intersubjective and morally normative view of humanity.

The importance we grant to copassion has also largescale societal dimensions: copassion strengthens the prerequisites of a good society. If "good society" is defined - as Cooper (2016) suggests - as a society "that maximizes the extent to which people can actualize their wants," copassion as a process of responding to the joy of a fellow human being is a contributor to synergy and the sense of moving toward our wants. If "good society" is defined in recognition-theoretic terms as a society where more and more individuals and groups are granted recognition (Honneth, 1995), then copassion as a recognitive attitude promotes a society where struggles for recognition give way to peaceful human co-existence. The quest for the definition of copassion is not only a search for a theoretical concept but also - and more fundamentally — a search for the foundations of flourishing humans, institutions embracing enchantment, and more humane societies.

\section{Declaration of conflicting interests}

The author(s) declared no potential conflicts of interest with respect to the research, authorship, and/or publication of this article. 


\section{Funding}

The author(s) received no financial support for the research, authorship, and/or publication of this article.

\section{ORCID iDs}

Anne Birgitta Pessi (iD https://orcid.org/0000-0002-1312-9538

Jenni Spännäri (iD https://orcid.org/0000-0002-8867-2420

\section{References}

Arntz, M., Gregory, T., \& Zierahn, U. (2016). The risk of automation for jobs in OECD countries: A comparative analysis (OECD Social, Employment, and Migration Working Papers No. 189). Organisation for Economic Co-operation and Development.

Aronson, H. B. (1980). Love and sympathy in Theravada Buddhism. Motilal Banarsidass.

Ashforth, B. E., \& Humphrey, R. H. (1995). Emotion in the workplace: A reappraisal. Human Relations, 48(2), 97-125.

Barber, L. K., Conlin Amanda, L., \& Santuzzi Alecia, M. (2019). Workplace telepressure and work-life balance outcomes. The Role of Work Recovery Experiences. Stress and Health, $35(3), 350-362$.

Barsade, S. G. (2002). The ripple effect: Emotional contagion and its influence on group behavior. Administrative Science Quarterly, 47(4), 644-675.

Batson, C. D., Ahmad, N., \& Lishner, D. A. (2009). Empathy and altruism. In S. J. Lopez \& C. R. Snyder (Eds.), The Oxford handbook of positive psychology (pp. 417-426). Oxford University Press.

Batson, C. D., Batson, J. G., Slingsby, J. K., Harrell, K. L., Peekna, H. M., \& Todd, R. M. (1991). Empathic joy and the empathy-altruism hypothesis. Journal of Personality and Social Psychology, 61(3), 413-426.

Batson, C. D., Early, S., \& Salvarani, G. (1997a). Perspective taking: Imagining how another feels versus imagining how you would feel. Personality and Social Psychology Bulletin, 23(7), 751-758.

Batson, C. D., Sager, K., Garst, E., Kang, M., Rubchinsky, K., \& Dawson, K. (1997b). Is empathy-induced helping due to self-other merging? Journal of Personality and Social Psychology, 73(3), 495-509.

Baumeister, R. F., \& Leary, M. R. (1995). The need to belong: Desire for interpersonal attachments as a fundamental human motivation. Psychological Bulletin, 117(3), 497-529.

Becker, M. W., Alzahabi, R., \& Hopwood, C. J. (2013). Media multitasking is associated with symptoms of depression and social anxiety. Cyberpsychology, Behavior, and Social Networking, 16(2), 132-135.

Bell, E., Winchester, N., \& Wray-Bliss, E. (2021). Enchantment in business ethics research. Journal of Business Ethics, 174, 251-262. https://doi.org/10.1007/s10551-020-04592-4

Bennett, J. (2001). The enchantment of modern life: Attachments, crossings, and ethics. Princeton University Press.

Bennett, J. (2010). Vibrant matter. Duke University Press.

Bermant, G., Talwar, C., \& Rozin, P. (2011). To celebrate positive psychology and extend its horizons. In K. M. Sheldon, T. B. Kashdan, \& M. F. Steger (Eds.), Designing positive psychology: Taking stock and moving forward (pp. 430438). Oxford University Press.

Boje, D. M., \& Baskin, K. (2011). Our organizations were never disenchanted. Enchantment by design narratives vs enchantment by emergence. Journal of Organizational Change Management, 24(4), 411-426.

Bono, J. E., \& Ilies, R. (2006). Charisma, positive emotions and mood contagion. The Leadership Quarterly, 17(4), 317-334.

Bradfield, B. (2013). Intersubjectivity and the knowing of inner experience finding space for a psychoanalytic phenomenology in research. Journal of Humanistic Psychology, 53, 263-282.

Brown, S. L., \& Brown, R. M. (2006). Selective investment theory: Recasting the functional significance of close relationships. Psychological Inquiry, 17(1), 1-29.

Cameron, K., Dutton, J. E., \& Quinn, R. E. (2003). Foundations of positive organizational scholarship. In K. Cameron, J. E. Dutton, \& R. E. Quinn (Eds.), Positive organizational scholarship: Foundations of a new discipline (pp. 3-13). Berrett-Koehler.

Carlsen, A., Arnulf, J., \& Weitao, Z. (2017). Inviting wonder in organization: Tiger, sandstone, horror, snowball. Management and Organization Review, 13(3), 675-685.

Carlsen, A., \& Dutton, J. (2011). Research alive: The call for generativity. In A. Carlsen \& J. E. Dutton (Eds.), Research alive: Exploring generative moments in doing qualitative research (pp. 12-24). Liber, Copenhagen Business School Press; Universitetsforlaget.

Carlsen, A., \& Sandelands, L. (2015). First passion: Wonder in organizational inquiry. Management Learning, 46(4), 373390.

Carlyle, T. (1991). Sartor resartus. Oxford University Press. (Original work published 1834)

Clark, C. (1987). Sympathy biography and sympathy margin. American Journal of Sociology, 93, 290-321.

Cooper, M. (2016). The fully functioning society: A humanistic-existential vision of an actualizing, socially just future. Journal of Humanistic Psychology, 56(6), 581-594.

Cragg, W. (2012). Ethics, enlightened self-interest, and the corporate responsibility to respect human rights: A critical look at the justificatory foundations of the UN framework. Business Ethics Quarterly, 2(1), 9-36.

Crossley, N. (1996). Intersubjectivity. The fabric of social becoming. SAGE.

Davies, O. (2003). A theology of compassion: Metaphysics of difference and the renewal of tradition. SCM Press.

Davis, J. B. (2012). The homo economicus conception of the individual: An ontological approach. In U. Mäki (Ed.), Handbook of the philosophy of science: Vol. 13. Philosophy of economics (pp. 459-482). Elsevier.

de Bloom, J., Kinnunen, U., \& Korpela, K. (2015). Recovery processes during and after work: Associations with health, work engagement, and job performance. Journal of Occupational and Environmental Medicine, 57(7), 732-742.

Deci, E. L., \& Ryan, R. M. (2000). The "what" and "why" of goal pursuits: Human needs and the self-determination of behavior. Psychological Inquiry, 11(4), 227-268.

De Jaegher, H., \& Di Paolo, E. (2007). Participatory sensemaking: An enactive approach to social cognition. Phenomenology and the Cognitive Sciences, 6(4), 485-507. 
De Vignemont, F., \& Singer, T. (2006). The empathic brain: How, when and why? Cognitive Sciences, 10, 435-441.

de Waal, F. (2009). The age of empathy. Nature's lessons for a kinder society. Harmony Books.

Du Plooy, B. (2014). Ubuntu and the recent phenomenon of the charter for compassion. South African Review of Sociology, 45(1), 83-100.

Dutton, J. E., \& Heaphy, E. D. (2003). The power of high-quality connections. In K. S. Cameron, J. E. Dutton, \& R. E. Quinn (Eds.), Positive organizational scholarship: Foundations of a new discipline (pp. 263-278). Berrett-Koehler.

Dutton, J. E., Lilius, J. M., \& Kanov, J. M. (2007). The transformative potential of compassion at work. In S. K. Piderit, R. E. Fry, \& D. L. Cooperrider (Eds.), Handbook of transformative cooperation: New designs and dynamics (pp. 107-126). Stanford University Press.

Dutton, J. E., Workman, C., \& Hardin, A. (2014). Compassion at work. The Annual Review of Organizational Psychology and Organizational Behavior, 1, 277-304.

Dutton, J. E., Worline, M. C., Frost, P. J., \& Lilius, J. M. (2006). Explaining compassion organizing. Administrative Science Quarterly, 51(1), 59-96.

Edmondson, A. C., \& Lei, Z. (2014). Psychological safety: The history, renaissance, and future of an interpersonal construct. Annual Review of Organizational Psychology and Organizational Behavior, 1(1), 23-43.

Elder-Vass, D. (2012). The reality of social construction. Cambridge University Press.

Endrissat, N., Islam, G., \& Noppeney, C. (2015). Enchanting work: New spirits of service work in an organic supermarket. Organization Studies, 36(11), 1555-1576.

Englander, M., \& Folkesson, A. (2014). Evaluating the phenomenological approach to empathy training. Journal of Humanistic Psychology, 54(3), 294-313.

Eurofound. (2017). The sixth European working conditions survey. https://www.eurofound.europa.eu/sites/default/files/ ef_publication/field_ef_document/ef1634en.pdf

Frazier, M. L., Fainshmidt, S., Klinger, R. L., Pezeshkan, A., \& Vracheva, V. (2017). Psychological safety: A meta-analytic review and extension. Personnel Psychology, 70(1), 113-165.

Fredrickson, B. L. (2013). Love 2.0. Hudson Street Press.

Fredrickson, B. L., Cohn, M., Coffey, K. A., Pek, J., \& Finkel, S. A. (2008). Open hearts build lives: Positive emotions, induced through loving-kindness meditation, build consequential personal resources. Journal of Personality and Social Psychology, 95, 1045-1062.

Fredrickson, B. L., \& Joiner, T. (2002). Positive emotions trigger upward spirals toward emotional well-being. Psychological Science, 13(2), 172-175.

Frey, C. B., \& Osborne, M. A. (2017). The future of employment: How susceptible are jobs to computerisation? Technological Forecasting and Social Change, 114, 254-228.

Frith, C. D., \& Frith, U. (2006). The neural basis of mentalizing. Neuron, 50, 531-534.

Ganegoda, D. B., \& Bordia, P. (2019). I can be happy for you, but not all the time: A contingency model of envy and positive empathy in the workplace. Journal of Applied Psychology, 104(6), 776-795.

Goss, D. (2005). Schumpeter's legacy? Interaction and emotions in the sociology of entrepreneurship. Entrepreneurship Theory and Practice, 29(2), 205-218.
Graham, G. (2007). The re-enchantment of the world. Oxford University Press.

Grant, A. M. (2008a). Does intrinsic motivation fuel the prosocial fire? Motivational synergy in predicting persistence, performance, and productivity. Journal of Applied Psychology, 93(1), 48-58.

Grant, A. M. (2008b). The significance of task significance: Job performance effects, relational mechanisms, and boundary conditions. Journal of Applied Psychology, 93(1), 108-124.

Greenwood, M. (2002). Ethics and HRM. A review and conceptual analysis. Journal of Business Ethics, 36, 261-278.

Grootaert, C., \& Van Bastelar, T. (2002). Understanding and measuring social capital: A multidisciplinary tool for practitioners. Directions in development. World Bank.

Guest, D. E. (2017). Human resource management and employee well-being: Towards a new analytic framework. Human Resource Management Journal, 27(1), 22-38.

Hadley, C. N. (2014). Emotional roulette? Symmetrical and asymmetrical emotion regulation outcomes from coworker interactions about positive and negative work events. Human Relations, 67(9), 1073-1094.

Hakanen, J., \& Van Dierendonck, D. (2011). Servant leadership and life satisfaction: The mediating role of justice, job control, and burnout. The International Journal of ServantLeadership, 7, 253-261.

Hamilton, W. D. (1964). The genetical evolution of social behaviour. Journal of Theoretical Biology, 7, 1-52.

Hoever, I. J., Van Knippenberg, D., Van Ginkel, W. P., \& Barkema, H. G. (2012). Fostering team creativity: Perspective taking as key to unlocking diversity's potential. Journal of Applied Psychology, 97(5), 982-996.

Hoffman, M. L. (1981). The development of empathy. In J. P. Rushton \& R. M. Sorrentino (Eds.), Altruism and helping behavior: Social, personality, and developmental perspectives (pp. 41-63). Lawrence Erlbaum.

Hofmeyer, A., Taylor, R., \& Kennedy, K. (2020). Fostering compassion and reducing burnout: How can health system leaders respond in the Covid-19 pandemic and beyond? Nurse Education Today, 94, 104502.

Honneth, A. (1995). The struggle for recognition. The moral grammar of social conflicts. Polity Press.

Ikäheimo, H., \& Laitinen, A. (2007). Analyzing recognition: Identification, acknowledgement, and recognitive attitudes towards persons. In B. van den Brink \& D. Owen (Eds.), Recognition and power: Axel Honneth and the tradition of critical social theory (pp. 33-56). Cambridge University Press.

Islam, G. (2012). Recognition, reification, and practices of forgetting. Ethical implications of human resource management. Journal of Business Ethics, 111(1), 37-48.

Kahneman, D. (2011). Thinking, fast and slow. Farrar, Straus and Giroux.

Kallinikos, J. (2003). Work, human agency and organizational forms: An anatomy of fragmentation. Organization Studies, 24(4), 595-618.

Katriel, T. (1993). Lefargen: A study in Israeli semantics of social relations. Research on Language and Social Interaction, 26(1), 31-53.

Kettunen, T. (2018). Compassion, copassion and organisational communication-Case of internal relations [Master's thesis]. University of Innsbruck School of Management, Faculty 
of Business and Management, Department of Organization and Learning.

Keyriläinen, M. (2020). Työolobarometri 2019 (Työ-Ja Elinkeinoministeriön Julkaistuja 2020:53) [Working Life Barometer 2019]. https://julkaisut.valtioneuvosto. fi/bitstream/handle/10024/162527/TEM_2020_53. pdf? sequence $=1$

Kohlberg, L. (1958). The development of modes of thinking and choices in years 10 to 16 [Doctoral dissertation]. University of Chicago.

Kohlberg, L. (1984). Essays on moral development: Vol. 2. The psychology of moral development: The nature and validity of moral stages. Harper \& Row.

Kolodinsky, R. W., Giacolone, R. A., \& Jurkiewicz, C. L. (2008). Workplace values and outcomes: Exploring personal, organizational and interactive workplace spirituality. Journal of Business Ethics, 81(2), 465-480.

Korchmaros, J. D., \& Kenny, D. A. (2001). Emotional closeness as a mediator of the effect of genetic relatedness on altruism. Psychological Science, 12(3), 262-265.

Korchmaros, J. D., \& Kenny, D. A. (2006). An evolutionary and close-relationship model of helping. Journal of Social and Personal Relationships, 23(1), 21-43.

Korsgaard, C. (1996). Creating the kingdom of ends. Cambridge University Press.

Landy, J., \& Saler, M. (2009). Introduction: The varieties of modern enchantment. In J. Landy \& M. Saler (Eds.), The re-enchantment of the world: Secular magic in a rational age (pp. 1-14). Stanford University Press. https://doi. org $/ 10.2307 /$ j.ctvr33bqt

Lawson, T. (2015). What is this "school" called neoclassical economics? In J. Morgan (Ed.), What is neoclassical economics? Debating the origins, meaning and significance (pp. 30-90). Routledge.

Lazarus, R. S. (1991). Emotion and adaptation. Oxford University Press.

Lee, R. L. M. (2010). Weber, re-enchantment and social futures. Time \& Society, 19(2), 180-192.

Lemberger, M. E., \& Lemberger-Truelove, T. L. (2016). Bases for a more socially just humanistic praxis. Journal of Humanistic Psychology, 56(6), 571-580.

Levine, M., Prosser, A., Evans, D., \& Reicher, S. (2005). Identity and emergency intervention: How social group membership and inclusiveness of group boundaries shape helping behavior. Personality and Social Psychology Bulletin, 31(4), 443-453.

Lilius, J. M., Worline, M. C., Dutton, J. E., Kanov, J. M., \& Maitlis, S. (2011). Understanding compassion capability. Human Relations, 64(7), 873-899.

Lindblom, J. (2007). Minding the body: Interacting socially through embodied action [Dissertation]. Linköping Studies in Science and Technology.

Lomas, T. (2016). The magic of "untranslatable" words: Building a positive cross-cultural lexicography. Scientific American, 27(4), 1-4.

Lynnette, S. M., \& Davis, J. R. (2004). Perceptions of dishonesty among two-year college students: Academic versus business situations. Journal of Business Ethics, 51(1), 63-73.

Lysova, E. I., Allan, B. A., Dik, B. J., Duffy, R. D., \& Steger, M. F. (2019). Fostering meaningful work in organizations: A multi-level review and integration. Journal of Vocational
Behavior, 110, 374-389. https://doi.org/10.1016/j.jvb. 2018.07.004

Maitlis, S., \& Ozcelik, H. (2004). Toxic decision processes: A study of emotion and organizational decision making. Organization Science, 15(4), 375-393. https://doi. org/10.1287/orsc. 1040.0070

Makransky, J. (2012). Chapter 4. Compassion in Buddhist psychology. In C. K. Germer \& R. D. Siegel (Eds.), Wisdom and compassion in psychotherapy (pp. 61-74). Guilford Press.

Marsh, A. A. (2016). Neural, cognitive, and evolutionary foundations of human altruism. Wiley Interdisciplinary Reviews: Cognitive Science, 7(1), 59-71.

Martela, F., \& Pessi, A. B. (2018). Significant work is about selfrealization and broader purpose: Defining the key dimensions of meaningful work. Frontiers in Psychology, 9, Article 363.

Mattila, M. (2019). Työ ja työntekijän oikeudet alustataloudessa [English summary] [Work and Workers' Rights in the Platform Economy]. Kalevi Sorsa Säätiö [Kalevi Sorsa Foundation]. https://sorsafoundation.fi/wpcontent/uploads/2019/04/Work-in-the-Platform-EconomySummary.pdf

Meyer, J. W., Drori, G. S., \& Hwang, H. (2006). Conclusion. In G. S. Drori, J. W. Meyer, \& H. Hwang (Eds.), Globalization and organization: World society and organizational change (pp. 258-274). Oxford University Press.

Morelli, S. A., Lieberman, M. D., \& Zaki, J. (2015). The emerging study of positive empathy. Social and Personality Psychology Compass, 9(2), 57-68.

Ndlovu, P. M. (2016). Discovering the spirit of ubuntu leadership. Compassion, community, and respect. Palgrave Macmillan.

Niedenthal, P. M., Barsalou, L. W., Winkielman, P., KrauthGruber, S., \& Ric, F. (2005). Embodiment in attitudes, social perception, and emotion. Personality and Social Psychology Review, 9(3), 184-211.

Nussbaum, B. (2003). African culture and ubuntu: Reflections of a South African in America. Perspectives (World Business Academy), 17(1), 1-12.

Nussbaum, M. C. (2006). Frontiers of justice: Disability, nationality, species membership. Harvard University Press.

Paakkanen, M., Martela, F., Hakanen, J., Uusitalo, L., \& Pessi, A. (2021). Awakening compassion in managers-A new emotional skills intervention to improve managerial compassion. Journal of Business and Psychology, 36, 10951108. https://doi.org/10.1007/s10869-020-09723-2

Pajarinen, M., \& Rouvinen, P. (2014). Computerization threatens one third of Finnish employment. ETLA Brief, 22, 1-6.

Persky, J. (1995). The ethology of homo economicus. Journal of Economic Perspective, 9(2), 221-231.

Pless, N., \& Maak, T. (2004). Building an inclusive diversity culture: Principles, processes and practice. Journal of Business Ethics, 54, 129-147.

Post, S. G., Underwood, J., Schloss, J. P., \& Hurlbut, W. B. (2002). Altruism and altruistic love: Science, philosophy, and religion in dialogue. Oxford University Press.

Putnam, R. D. (2001). Social capital: Measurement and consequences. Isuma: Canadian Journal of Policy Research, 2, 41-51.

Racko, G. (2019). The values of economics. Journal of Business Ethics, 154(1), 35-48. 
Renault, E. (2010). Taking on the inheritance of critical theory: Saving Marx by recognition? In C. F. Zurn \& H.-C. Schmidt, am Busch (Eds.), The philosophy of recognition. Historical and contemporary perspectives (pp. 241-256). Lexington Books.

Ricoeur, P. (1975). La metaphor vive [The Rule of Metaphor]. Éditions du Seuil.

Ricoeur, P. (1983). Temps et récit, tome 1 [Time and Narrative, Volume 1]. Éditions du Seuil.

Ricoeur, P. (2004). Parcours de la reconnaissance [The Course of Recognition]. Éditions Stock.

Ritzer, G. (2005). Enchanting a disenchanted world. Revolutionizing the means of consumption. Pine Forge Press.

Rössler, B. (2007). Work, recognition, emancipation. In B. van den Brink \& D. Owen (Eds.), Recognition and power. Axel Honneth and the tradition of critical social theory (pp. 135163). Cambridge University Press.

Scheler, M. (2008). The nature of sympathy. Transaction Publishers. (Original work published 1923)

Seppälä, E., Rossomando, T., \& Doty, J. (2013). Social connection and compassion: Important predictors of health and well-being. Social Research, 80(2), 411-430.

Shahzad, K., \& Muller, A. (2016). An integrative conceptualization of organizational compassion and organizational justice. A sensemaking perspective. Business Ethics: A European Review, 25(2), 144-158.

Singer, T., \& Klimecki, O. M. (2014). Empathy and compassion. Current Biology, 24, R875-R878.

Singer, T., \& Lamm, C. (2009). The social neuroscience of empathy. Annals of the New York Academy of Sciences, 1156, 81-96.

Smith, A. (1984). The theory of moral sentiments. Liberty Fund.

Strati, A. (1996). Organizations viewed through the lens of aesthetics. Organization, 3(2), 209-218.

Suddaby, R., Ganzin, M., \& Minkus, A. (2017). Craft, magic and the re-enchantment of the world. European Management Journal, 35(3), 285-296.

Telle, N.-T., \& Pfister, H.-R. (2015). Positive empathy and prosocial behavior: A neglected link. Emotion Review, 8(2), $1-10$.

Tomasello, M. (1999). The cultural origins of human cognition. Harvard University Press.

Trivers, R. L. (1971). The evolution of reciprocal altruism. Quarterly Review of Biology, 46(1), 35-57.

Turiel, E. (2002). The culture of morality: Social development, context, and conflict. Cambridge University Press.
Välikangas, L., \& Sevón, G. (2010). Of managers, ideas and jesters, and the role of information technology. The Journal of Strategic Information Systems, 19(3), 145-153.

Varga, S., \& Gallagher, S. (2011). Critical social philosophy, Honneth, and the role of primary intersubjectivity. European Journal of Social Theory, 15(2), 243-260.

Venema, H. I. (2000). Identifying selfhood: Imagination, narrative, and hermeneutics in the thought of Paul Ricoeur. State University of New York Press.

Vuori, T. O., \& Huy, Q. N. (2016). Distributed attention and shared emotions in the innovation process: How Nokia lost the smartphone battle. Administrative Science Quarterly, 61(1), 9-51.

Waldinger, R. J., Cohen, S., Schulz, M. S., \& Crowell, J. A. (2014). Security of attachment to spouses in late life concurrent and prospective links with cognitive and emotional well-being. Clinical Psychological Science, 3(4), 1-45.

Wang, L., Malhotra, D., \& Murnighan, J. K. (2011). Economics education and greed. Academy of Management Learning and Education, 10, 643-660.

Weber, M. (1946). Essays in sociology. Oxford University Press.

Wilson, D. S. (2016). Does altruism exist? Culture, genes, and the welfare of others. Yale University Press.

World Economic Forum. (2016, January). The future of jobs. Employment, skills and workforce strategy for the fourth industrial revolution [Global challenge insight report]. https://www3.weforum.org/docs/WEF_Future_of_Jobs. pdf

Xanthopoulou, D., Bakker, A. B., Oerlemans, W. G. M., \& Koszucka, M. (2018). Need for recovery after emotional labor: Differential effects of daily deep and surface acting. Journal of Organizational Behavior, 39(4), 481-494.

Zahavi, D. (2010). Empathy, embodiment and interpersonal understanding. From Lipps to Schutz. Inquiry, 53, 541-558.

Zapf, D., Kern, M., Tschan, F., Holman, D., \& Semmer, N. K. (2021). Emotion work: A work psychology perspective. Annual Review of Organizational Psychology and Organizational Behavior, 8(1), 139-172.

Zlatev, J., Racine, T. P., Sinha, C., \& Itkonen, E. (2008). Intersubjectivity. What makes us human. In J. Zlatev (Ed.), The shared mind. Perspectives on intersubjectivity (pp. 2 14). John Benjamins.

Zurn, C. F. (2010). Introduction. In C. F. Zurn \& H.-C. Schmidt am Busch (Eds.), The philosophy of recognition. Historical and contemporary perspectives (pp. 1-120). Lexington Books. 